\title{
Genetic and genomic analyses for economically important traits and their applications in molecular breeding of cultured fish
}

\author{
TONG JinGou ${ }^{1 *} \&$ SUN XiaoWen ${ }^{2}$ \\ ${ }^{1}$ State Key Laboratory of Freshwater Ecology and Biotechnology, Institute of Hydrobiology, Chinese Academy of Sciences, Wuhan 430072, \\ China; \\ ${ }^{2}$ Heilongjiang Fisheries Research Institute, Chinese Academy of Fishery Sciences, Harbin 150070, China
}

Received September 9, 2014; accepted November 13, 2014; published online January 21, 2015

\begin{abstract}
The traits of cultured fish must continually be genetically improved to supply high-quality animal protein for human consumption. Economically important fish traits are controlled by multiple gene quantitative trait loci (QTL), most of which have minor effects, but a few genes may have major effects useful for molecular breeding. In this review, we chose relevant studies on some of the most intensively cultured fish and concisely summarize progress on identifying and verifying QTLs for such traits as growth, disease and stress resistance and sex in recent decades. The potential applications of these major-effect genes and their associated markers in marker-assisted selection and molecular breeding, as well as future research directions are also discussed. These genetic and genomic analyses will be valuable for elucidating the mechanisms modulating economically important traits and to establish more effective molecular breeding techniques in fish.
\end{abstract}

aquaculture fish, economic traits, QTL, major genes, molecular markers, molecular breeding

Citation: Tong JG, Sun XW. Genetic and genomic analyses for economically important traits and their applications in molecular breeding of cultured fish. Sci China Life Sci, 2015, 58: 178-186, doi: 10.1007/s11427-015-4804-9

Fish are produced to supply high-quality protein to the market through breeding of new fish strains with better traits, such as fast growth, high resistance to disease and stress, and a high feed conversion rate (FCR). Fish-breeding methodologies have developed rapidly in past decades, from traditional selection and hybridization to modern biotechnologies, such as marker-assisted selection and molecular breeding. Although selection is the basis for all breeding techniques, traditional family or population-based selection is usually less efficient and the breeding programs may take a long period of time to develop. Most economically important traits in fish, such as growth rate, disease resistance, and sex, are controlled by multiple genes, known as quantitative trait loci (QTL). Most of these genes have minor effects, but several may have major effects on traits. Theoret-

*Corresponding author (email: jgtong@ihb.ac.cn) ically, if genes and genetic markers associated with traits of interest are identified, the genetic variants could be used as tools in marker-assisted selection (MAS) analyses. The idea of using genetic markers during selective breeding has been proposed since the 1960s, but the genetic basis for economically important traits in animals including fish has not been analyzed effectively due to a shortage in high-resolution and powerful techniques. However, genetic mechanisms underlying the economically important traits in fish have been studied more effectively with the development of quantitative genetics, molecular genetics, structural and functional genomics, and molecular marker technologies. In particular, an understanding of QTL from zero to the present provides a solid basis for developing fish molecular breeding strategies.

The tools to genetically analyze economic traits in fish 
include (i) developing a large number of molecular markers; (ii) constructing medium and high-density genetic linkage maps and conducting QTL/expression quantitative trait locus (eQTL) analyses throughout the whole genome; (iii) using a candidate gene approach or an association study; (iv) conducting a bulked segregant analysis (BSA); (v) linkage disequilibrium (LD), or LD associate mapping; and (vi) genome-wide association study (GWAS).

Molecular markers are one of the most powerful tools for genetic analyses of fish's economically important traits. In the early stages of this field, genetic variations were represented by a limited number of less polymorphic allozyme loci. Then dominant markers, such as restriction fragment length polymorphism (RFLP), randomly amplified polymorphic DNA (RAPD), and amplified fragment length polymorphism (AFLP), were developed one after another. In recent years, two types of DNA markers-microsatellite or simple sequence repeat (SSR) and single nucleotide polymorphisms (SNPs) - have been widely used in genetic analyses due to their wide genome distribution and high rate of polymorphisms [1]. Molecular breeding includes molecular marker-assisted selection, transgenic breeding, and computer-based molecular design breeding [2]. In the late 1990s, the United States, Japan, Norway, Canada, and Australia initiated genome projects in several aquatic animals. Chinese scientists also started genome sequencing projects for oyster, scallop, shrimp, half-smooth tongue sole, common carp, yellow croaker, grass carp, and grouper. Silver carp, bighead carp, bluntsnout bream, and gibeio carp will also be decoded one after another in the near future. The great advances in genomics, including structural, functional, and comparative genomics, have provided new insights into molecular breeding studies [3-5]. In this review, we will concisely summarize current genetic and genomic analyses for economically important traits and discuss future directions and prospects for fish molecular breeding.

\section{Status of genetic and genomic studies on economically important traits in fish}

\subsection{Genetic linkage maps}

Since the first genetic linkage map was published for tilapia in 1998 [6], genetic maps of various densities have been published on some important aquaculture species, and many of these maps used co-dominant genetic markers, such as microsatellites and SNPs. More high-density maps of aquatic species have been reported with the advances in molecular marker technology and increased financial input. Up to 2010, about 30 aquatic animals had publicly accessible genetic maps [7]. However, more aquaculture fish have been added in the past three years, including three of the four major Chinese carp, among them grass carp, silver carp, and bighead carp, and other important aquaculture fish (Table 1).

\subsection{QTL analysis for growth traits}

Growth is one of the most important economic traits of all aquaculture species. Up to 2012, QTL analyses have been conducted in more than 20 aquatic species [7], and growth is the most popular trait studied. Wang et al. [21] used 380 F1 Asian seabass to identify five major QTLs and 27 potential QTLs. Of them, three major QTLs for body weight, total length, and body length were located at a similar linkage group 2 (LG2) position with the nearby Lca287 microsatellite and accounted for $28.8 \%, 58.9 \%$, and $59.7 \%$ of the phenotypic variations. The other two major QTLs for body weight were located at another LG2 position. These five major QTLs have been confirmed in two other Asian seabass populations [22]. Further QTL fine mapping of the Asian seabass growth trait identified three candidate "growth genes" (cathepsin D, KCTD15, and csmd2) affecting body weight, body length, and total length [10]. The

Table 1 Medium and high-density genetic linkage maps for some economically important fish species

\begin{tabular}{|c|c|c|c|c|c|c|c|}
\hline Species & Type of markers & No. of markers & $\begin{array}{l}\text { Average distance } \\
(\mathrm{cM})\end{array}$ & Year & $\begin{array}{l}\text { No. of linkage } \\
\text { groups }\end{array}$ & $\begin{array}{c}\text { Chromosome No. of } \\
\text { haploid genome }\end{array}$ & References \\
\hline Pseudosciaena crocea & AFLP and SSR & 375 & $>9$ & 2007 & 24 & 24 & {$[8]$} \\
\hline Ctenopharyngodon idella & SSR and SNP & 279 & 4.2 & 2010 & 24 & 24 & {$[9]$} \\
\hline Lates calcarifer & SSR and SNP & 790 & 3.4 & 2011 & 20 & 20 & {$[10]$} \\
\hline Oncorhynchus mykiss & SSR and SNP & 1,459 & 2.29 & 2012 & 29 & 30 & {$[11]$} \\
\hline Paralichthys olivaceus & SSR & 1,487 & 1.22 & 2012 & 24 & 24 & {$[12]$} \\
\hline Scophthalmus maximus & SSR and SNP & 487 & 3.3 & 2013 & 24 & 22 & {$[14]$} \\
\hline Oreochromis spp & SSR & 401 & 3.3 & 2013 & 22 & 22 & {$[15]$} \\
\hline Hypophthalmichehys molitrix & SSR & 703 & 2.2 & 2013 & 24 & 24 & {$[16]$} \\
\hline Cyprinus carpio & SSR and SNP & 1,209 & 3.5 & 2013 & 50 & 50 & {$[17]$} \\
\hline Aristichthys nobilis & SSR & 659 & 2.9 & 2014 & 24 & 24 & {$[18]$} \\
\hline Ictalurus punctatus & SNP & 62,870 & 0.4 & 2014 & 29 & 29 & {$[19]$} \\
\hline Salmo salar & SNP & 6,458 & - & 2014 & 29 & 29 & {$[20]$} \\
\hline
\end{tabular}


function of the cathepsin D gene in humans involves cell proliferation and cell growth; therefore, cathepsin D may also be a major "growth gene" in Asian seabass.

O'Malley et al. [23] identified QTLs for body weight in rainbow trout on 10 different LGs. Wringe et al. [24] used additional backcrossed families and SSR markers to confirm the O'Malley et al.'s results and found several major candidate growth genes (e.g., GH2 and Pax7). Reid et al. [25] identified a QTL for body weight in two LGs (AS8 and 11) of Atlantic salmon, and reported that it was homologous to the growth QTL in rainbow trout. Houston et al. [26] identified QTLs for body weight in LG1 and LG5 of Atlantic salmon. Gutierrez et al. [27] further used a 6.5 K SNP chip to identify QTLs in six LGs at the genomic level. Cnaani et al. [28,29] identified a QTL for tilapia growth on LG23, which is the linkage group with the genetic sex-determining region. Song et al. [12] used 1487 SSRs to produce a high-density genetic linkage map and successfully identified a QTL affecting body weight in LG14 of Japanese flounder.

Some reports have used a candidate gene approach to identify growth-related genes and molecular markers in fish. Tao and Boulding [30] found polymorphisms in the growth hormone gene $(G H)$ that were significantly associated with growth rate of Arctic charr (Salvelinus alpinus). Li et al. [31] reported an SNP in the insulin-like growth factor- (IGF)1 gene $5^{\prime}$ untranslated region (UTR) of largemouth bass (Micropterus salmoides). Sun et al. [32] reported that two SNPs in exon 3 of the myostatin (MSTN) gene were significantly related to body weight and Fulton's factor in common carp. Liu et al. [33] also found that a SNP in the MSTN 3' UTR was very significantly associated with total length, body length, and body weight of bighead carp.

\subsection{QTL for disease resistance}

Diseases strongly influence the aquaculture industry. Infectious hematopoietic necrosis (IHN) disease, for instance, is an acute infectious virus disease that affects salmonids in the northern hemisphere. IHN can result in fingerling and larval fish mortality rates of $70 \%-100 \%$. Identifying immune or disease-resistant molecular markers would provide theoretical and technical bases for breeding anti-disease characteristics. Rodriguez et al. [34] used rainbow trout and steelhead trout hybrids in a backcross with rainbow trout to produce $70 \mathrm{BC} 1$ families. The offspring were exposed to an IHN infection, and the phenotypes were categorized as: 1 (death) and 0 (survival). As a result, six SSR markers were related to IHN resistance based on BSA screening.

Ozaki et al. [35] used 51 SSRs across all rainbow trout LGs in a BC1 family QTL analysis and found two QTLs for anti-infectious pancreatic necrosis virus (IPNV) disease on LG21 in Atlantic salmon. Baerwald et al. [36] used 143
SSRs and AFLP markers in a large F2 family ( $n=480)$ and found a QTL on Omy9 associated with whirling disease in young salmonids. This QTL was confirmed in three other families. Several authors have reported QTLs for IPNV, and most show that the anti-IPNV loci are located on LG21 [37-40], indicating that rainbow trout and Atlantic salmon anti-IPNV QTLs may be evolutionarily conserved. The genetic effects of Atlantic salmon anti-IHN QTLs have been validated in other studies [41]. Fuji et al. [42] used a segregated population and located a single major QTL controlling resistance to lymphocystis disease on LG15 in Japanese flounder with a phenotypic variation value of $50 \%$. Further study confirmed that an SSR locus within that QTL was closely related with a phenotype for lymphocystis disease resistance [43].

Molecular markers associated with disease resistance are also found on immune-related genes. For example, Palti et al. [44] reported that MHCII alleles are significantly associated with anti-IHN in rainbow trout. Zhang et al. [45] and $\mathrm{Xu}$ et al. [46] successfully screened for anti-disease molecular markers by comparing the polymorphisms of Japanese flounder groups susceptible and resistant to Vibrio anguillarum.

\subsection{QTL for feed conversion rate}

FCR is one of the most important economic traits in fish, as fish with a better FCR increase profits. QTLs for FCR have been reported in cattle [47], pigs [48] and chickens [49]. Some SNPs in the growth hormone receptor $(G H R)$, neuropeptide Y $(N P Y)$, uncoupling protein 3 (UCP3), ghrelin $(G H R L)$, and $I G F-2$ genes of cattle affect FCR. [50]. Liu [51] used AFLP markers to construct a catfish genetic map and found a QTL associated with FCR. Zimmerman et al. [52] revealed three QTLs for the number of pyloric caeca in three LGs of rainbow trout, and this is an important index associated with FCR. Although FCR studies have been reported in common carp from the Heilongjiang Fisheries Research Institute of the Chinese Academy of Fishery Sciences [53], QTL analyses for FCR in aquaculture fish are rarely reported.

\subsection{QTL for sex determination}

Sex phenotype and sex determination in fish have specific evolutionary status and diversity. Males and females of some species have significant differences in growth rate or commercial value; therefore, monosex fish culture is a promising strategy. The sex-determining (SD) loci and QTLs have been studied in a limited number of fish, such as tilapia [54], rainbow trout [55], and salmonids [56]. Previous studies have demonstrated that sex QTLs are located on LG1, 2, 3, 6, and 23 of tilapia [29,54,57]. Eshel et al. [58,59] reported a major candidate sex QTL that is considered the 
sexdetermining region in tilapia. Fifty-one genes in this region have been annotated, and 10 have been confirmed. The anti-Müllerian hormone gene is the most differentially expressed gene in male and female tilapia. Sun et al. [60] recently published several sex-specific markers, and one is tightly linked with the sex-determining region discovered by Eshel et al. The sex-determining locus in rainbow trout is located on the LG of RT10 [61], and this locus also significantly affects thermo-resistance and body length [62]. The sex-determining regions in Artic charr [63], brown trout [64], and Atlantic salmon [65] are located on the LGs of AC4, BT28, and AS1, respectively. Woram et al. [66] compared LGs of sex-determining loci in four salmonids and found that although the nucleotide sequences flanking the sex-determining loci were well-conserved, the SD LGs were diverse, suggesting that the regions underwent different recombination events. Loukovitis et al. [67] located growth and sex-determining QTLs in gilthead sea bream and showed that these two traits have similar genetic control in LG21. Martínez et al. [68] located a sex QTL on LG5 of turbot and proposed a ZZ/ZW sex-determining mechanism. Viñas et al. [69] also found a major sex QTL on turbot LG5. These findings suggest that the sex-determining genes may occur on turbot LG5. Song et al. [13] used high-density genetic maps to locate seven sex QTLs on the half-smooth tongue sole LG1f, LG14f, and LG1m. Additional study by Chen et al. [70] provided insight into ZW sex chromosome evolution and identified sex-determining genes, such as dmrtl and neurl3.

\subsection{QTL analysis for anti-stress traits}

Recent evidence shows that some fish may have sufficient genetic variation to adapt to environmental changes, such as changes in temperature and salinity. For example, cold tolerance in the stickleback may be strongly selected [71]. Growth of tilapia slows markedly when temperature drops below the optimum, and can cause death. Cnaani et al. [28] located a marker associated with cold resistance and body size in a F2 hybrid between Mozambique and Nile tilapia. Moen et al. [72] confirmed that cold-tolerance QTL exists on LG23 in tilapia. Rainbow trout have weak tolerance to high temperature; however, Jackson et al. [73] located thermo-tolerant QTLs on two LGs and identified two tightly linked markers. Danzmann et al. [74] further reported that one microsatellite was associated with thermo-tolerance in rainbow trout, which was confirmed by Perry et al. [75]. Perry et al. [62] further found that the Ssa20.19NUIG sex marker is associated with body length and thermo-resistance in rainbow trout. Sun et al. [76] located a cold resistance locus on common carp LG5. Rengmark et al. [77] reported a high salinity-tolerance gene, while Norman et al. [78] compared QTLs for salinity tolerance among the salmonid genomes and found that the QTLs were distributed on nine different LGs.

\section{Applications and discussion of molecular breeding}

\subsection{Progress of applied molecular breeding studies}

Many aquatic geneticists have used genetic or molecular markers as tools to perform parentage and molecular marker-assisted selection [4]. Common carp is a fish cultured worldwide and is one of the most important fish cultured in China. Chinese scientists have achieved good breeding results using genetic distances of female and male parents to design a mirror carp mating scheme. In common carp, bighead carp and other species, Chinese scientists confirmed a positive correlation between growth traits and the number of advantageous variants from candidate major genes. QTL analyses have reported good results from selective breeding programs for spindle-type mirror carp and slim-type common carp [4]. A multi-locus congruent breeding technique has been proposed, based mainly on common carp studies, and provides a basis for establishing a molecular breeding technique in fish (Figure 1).

Although many research programs are progressing, studies in a few species have shown favorable effects on breeding for anti-disease traits. Fuji et al. [42] found an SSR allele associated with IPN, and used it during large-scale anti-IPN selective breeding and fingerling production [43]. Selective breeding of gibeio carp has made good progress using anti-myxosporean-related MHC alleles as molecular markers [79]. Chen's group selected for anti-disease Japanese flounder using BSA and QTL analyses to identify anti-Vibrio-anguillarum-related markers [80,81].

Sex markers have been used in fish species with large sex differences. Chinese scientists have developed strategies for large-scale YY supermale and XY all-male yellow catfish based on the combination of artificial gynogenesis, sex reversal, and $\mathrm{X}$ - and Y-chromosome-specific molecular markers, and these methods have been used in commercial production [82-84]. Female-specific AFLP and sex-specific SSR markers have been isolated in half-smooth tongue sole $[85,86]$, and facilitate sex identification during early growth. Sex determination and sex marker studies have been conducted in Nile tilapia [59,60], and sex-marker-assisted selection is expected to be commercialized in the near future.

\subsection{Discussion of and directions for molecular breed- ing}

People continue to consume more fish protein with the increased demand for foods with beneficial health effects. Aquatic products have become increasingly popular in recent decades, but the increase in aquatic production relies heavily on aquaculture of a limited number of species, such as grass carp, silver carp, bighead carp, common carp, crucian carp, rainbow trout, and tilapia, which account for more than two-thirds of total annual world fish production. 


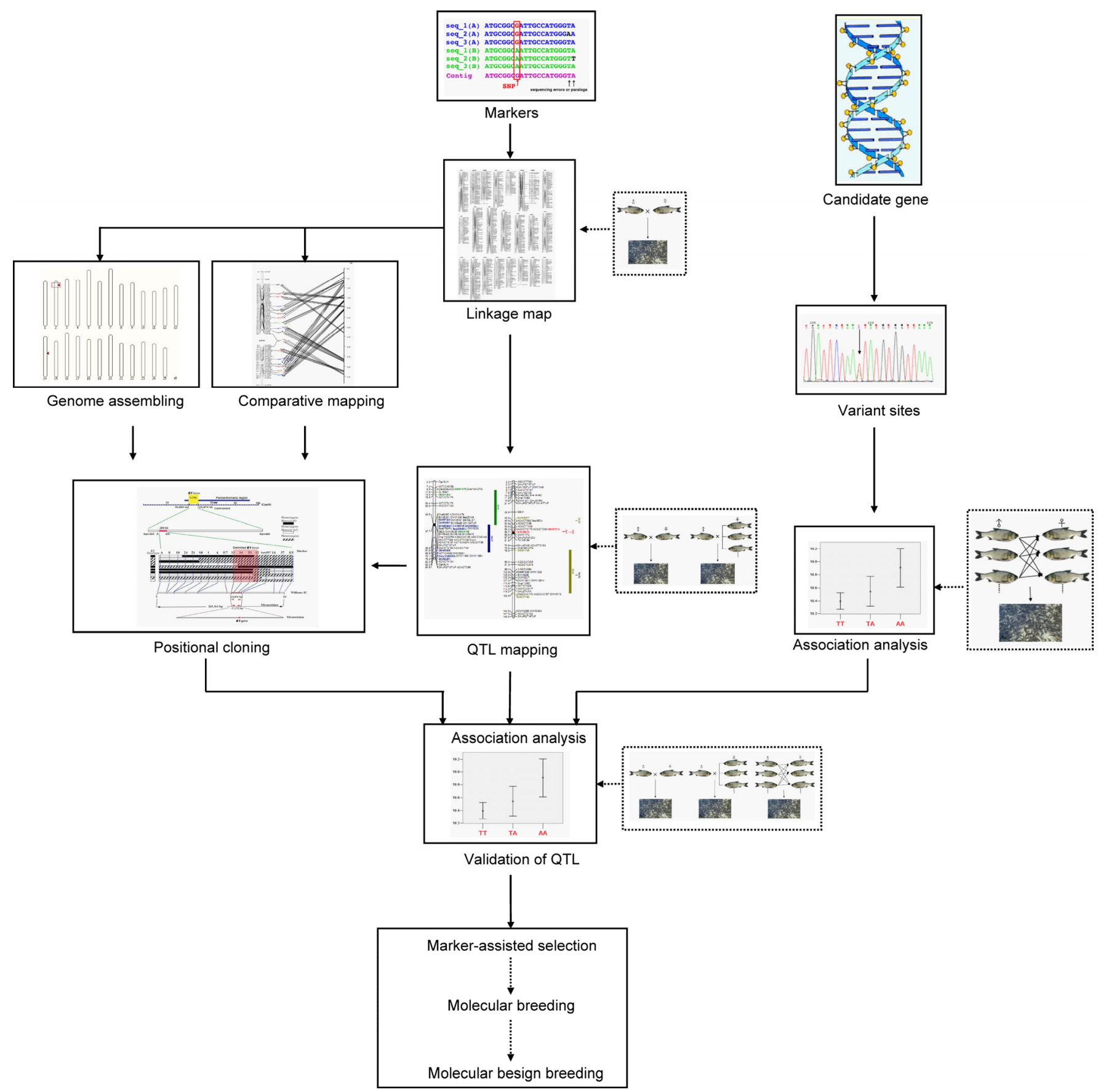

Figure 1 Fish molecular breeding strategies.

Some fish species have met poor traits after many years of aquaculture, such as early sex maturation, weak stress resistance, or frequent disease outbreaks. These features demand selection and genetic improvement for better strains and varieties. Up to now, more than 60 fish and shellfish have undergone selective breeding, and traits of interest have focused on growth and other phenotypes, such as anti-disease and anti-stress (e.g., cold- and thermo-resistant). However, other economically important traits, such as FCR and intramuscular bone content, have received less attention, probably because the phenotypes for these traits are difficult to measure and study [4]. It is expected that future scientists will consider these traits and elucidate the genetic mechanisms underlying them so that molecular breeding for composite traits would be possible.

Genomes of the half-smooth tongue sole and common carp have been sequenced and assembled at the Chinese Academy of Fishery Sciences [70,87]. After several years of efforts by the scientists there, hundreds of QTLs and molecular markers for growth traits have been found in various 
common carp strains, as well as markers for immuno-related and cold-resistance genes and markers. QTLs associated with sex and growth-related traits have been identified, and the sex chromosome sequences have provided a solid foundation for molecular and mono-sex breeding studies in half-smooth tongue sole. Scientists have also identified many QTLs for various traits in salmonids, tilapia, and flounder. Nevertheless, QTL fine mapping has been rarely reported in cultured fish. Currently, QTL analyses in fish have provided LG intervals, and those markers tightly linked with an interval may be suitable for MAS. However, a more powerful method is to identify genes from those intervals, screen the SNPs at the population level, and apply the SNPs in a molecular breeding program through quantitative trait nucleotides [88]. Genes in the QTL interval that affect traits of interest should generally meet the following criteria: (i) the function of the gene is known and it plays one of the most important roles affecting the trait(s); (ii) the gene has been subjected to functional studies in this or other species, such as gene transfer or knockdown; (iii) the gene is expressed in tissues or organs that involve traits of interest; and (iv) the gene modulates the trait throughout development. Further confirmation is needed for those genes and markers in different populations and families. Only confirmed genes and linked markers can be used for MAS or molecular breeding.

Although QTL analyses screen for trait-related loci throughout a fish genome, it is usually used for family material, which makes QTL results difficult to confirm in other populations or families. LD analysis or LD mapping (usually of population material) is used to localize QTLs for more polymorphic sites and at higher resolution. Therefore, LD mapping is a powerful method to identify the functions of major-effect genes or high-resolution QTL [89]. High-throughput DNA sequencing and SNP-detecting technologies have been used with LD mapping to identify possible advantageous alleles of genes in fish. As mentioned above, some reports have demonstrated that different QTLs for sex, anti-disease (or stress resistance), and growth traits may harbor the same LG on a similar or nearby position. Fine mapping of those QTL intervals with multiple phenotypes could be conducted with LD mapping, comparative genomics, and other cost-effective methods to identify and confirm novel genes and their associated markers for molecular breeding.

A candidate gene approach [90] together with the BSA method is an effective way to identify trait-associated genes and molecular markers in species with or without genetic maps. The BSA method has been applied to discover sex and disease-resistance genes in aquatic animals [34,91], but it has rarely been used to identify major candidate growth genes or those for other economically important traits. In the future, BSA should be more frequently used in eQTL to identify major genes and associated markers, particularly when used in combination with high-throughput next gen- eration sequencing.

GWAS is a powerful technology to reveal trait-related genes and alleles. However, GWAS relies heavily on the development and genotyping of thousands of molecular markers throughout the target genome. As re-sequencing costs are high, GWAS has only been used in humans and a few domestic animals. Fortunately, whole-genome sequencing is complete or is nearly complete in several cultured fish species, and sequences of more fish genomes will be available in the near future. Thus, GWAS will be used for more frequent genetic analyses of economically important traits in cultured fish.

Scientists have proposed a molecular design breeding concept with the rapid accumulation of known genes and genetic variants that affect economically important traits of domestic animals and plants. This is to integrate major-effect genes and favorable variants to create new strains and varieties to improve agricultural performance [2]. Scientists from the Chinese Academy of Sciences also proposed a molecular module design breeding concept to establish new breeding biotechnology in the new era. Molecular design breeding or molecular module design breeding is based on molecular docking of three-dimensional biomacromolecular data, computational analysis, integration, and simulation to select the best breeding strategy for a computer virtual design before initiating an actual breeding program [92]. Further understanding of fish genomes and identifying large numbers of QTLs, candidate major genes, and associated markers will reveal the potentials of molecular breeding. Enriching omics information and molecular elements (genes and markers) for major traits in cultured fish will allow molecular (module) design breeding technology to achieve great progress in the near future.

This review was supported by the National Basic Research Program of China (2010CB126305). We thank Feng Xiu, Wang XinHua, and Fu BeiDe from the Institute of Hydrobiology, and Zhang XiaoFeng from the Heilongjiang Fisheries Research Institute for their assistance.

1 Liu ZJ, Cordes JF. DNA marker technologies and their applications in aquaculture genetics. Aquaculture, 2004, 238: 1-37

2 Peleman JD, van der Voort JR. Breeding by design. Trends Plant Sci, 2003, 8: 330-334

3 Varshney RK, Graner A, Sorrells ME. Genomics-assisted breeding for crop improvement. Trends Plant Sci, 2005, 10: 621-630

4 Sun XW. Molecular Breeding of Fish (in Chinese). Beijing: China Ocean Press, 2010

5 Gui JF, Zhu ZY. Molecular basis and genetic improvement of economically important traits in aquaculture animals. Chin Sci Bull, 2012, 57: 1751-1760

6 Kocher TD, Lee WJ, Sobolewska H, Penman D, McAndrew B. A genetic linkage map of a cichlid fish, the tilapia (Oreochromis niloticus). Genetics, 1998, 148: 1225-1232

7 Yue GH. Recent advances of genome mapping and marker-assisted selection in aquaculture. Fish Fisheries, 2014, 15: 376-396

8 Ning Y, Liu X, Wang ZY, Guo W, Li YY, Xie FJ. A genetic map of large yellow croaker Pseudosciaena crocea. Aquaculture, 2007, 264 : 16-26 
9 Xia J H, Liu F, Zhu ZY, Fu JJ, Feng JB, Li JL, Yue GH. A consensus linkage map of the grass carp (Ctenopharyngodon idella) based on microsatellites and SNPs. BMC Genomics, 2010, 11: 135

10 Wang C M, Bai Z Y, He XP, Lin G, Xia JH, Sun F, Lo LC, Feng F, Zhu ZY, Yue GH. A high-resolution linkage map for comparative genome analysis and QTL fine mapping in Asian seabass, Lates calcarifer. BMC Genomics, 2011, 12: 174

11 Palti Y, Genet C, Gao G, Hu Y, You FM, Boussaha M, Rexroad CE 3rd, Luo MC. A second generation integrated map of the rainbow trout (Oncorhynchus mykiss) genome: analysis of conserved synteny with model fish genomes. Mar Biotechnol, 2012, 14: 343-357

12 Song W, Pang R, Niu Y, Gao F, Zhao Y, Zhang J, Sun J, Shao C, Liao X, Wang L, Tian Y, Chen S. Construction of high-density genetic linkage maps and mapping of growth-related quantitative trait loci in the Japanese flounder (Paralichthys olivaceus). PLoS One, 2012, 7: e50404

13 Song W, Li Y, Zhao Y, Liu Y, Niu Y, Pang R, Miao G, Liao X, Shao C, Gao F, Chen S. Construction of a high-density microsatellite genetic linkage map and mapping of sexual and growth-related traits in half-smooth tongue sole (Cynoglossus semilaevis). PLoS One, 2012, 7: e52097

14 Hermida M, Bouza C, Fernández C, Sciara AA, Rodríguez-Ramilo ST, Fernández J, Martínez P. Compilation of mapping resources in turbot (Scophthalmus maximus): a new integrated consensus genetic map. Aquaculture, 2013, 414: 19-25

15 Liu F, Sun F, Li J, Xia JH, Lin G, Tu RJ, Yue GH. A microsatellite-based linkage map of salt tolerant tilapia (Oreochromis mossambicus $\times$ Oreochromis spp.) and mapping of sex-determining loci. BMC Genomics, 2013, 14: 58

16 Guo W, Tong J, Yu X, Guo W, Wang X, Liu H, Feng X, Sun Y, Liu $\mathrm{L}, \mathrm{Fu} \mathrm{B}$. A second generation genetic linkage map for silver carp (Hypophthalmichehys molitrix) using microsatellite markers. Aquaculture, 2013, 412: 97-106

17 Zhao L, Zhang Y, Ji P, Zhang X, Zhao Z, Hou G, Huo L, Liu G, Li C, $\mathrm{Xu}$ P, Sun X. A dense genetic linkage map for common carp and its integration with a BAC-based physical map. PLoS One, 2013, 8:e63928

18 Zhu C, Tong J, Yu X, Guo W, Wang X, Liu H, Feng X, Sun Y, Liu L, $\mathrm{Fu}$ B. A second-generation genetic linkage map for bighead carp (Aristichthys nobilis) based on microsatellite markers. Anim Genet, 2014, 45: 699-708

19 Li Y, Liu S, Qin Z, et al. A High-density genetic linkage map of channel catfish for the assembly of reference whole genome sequences. In: Plant and Animal Genome XXII Conference. Plant and Animal Genome, 2014

20 Gonen S, Lowe N R, Cezard T, Gharbi K, Bishop SC, Houston RD. Linkage maps of the Atlantic salmon (Salmo salar) genome derived from RAD sequencing. BMC Genomics, 2014, 15: 166

21 Wang CM, Lo LC, Zhu ZY, Yue GH. A genome scan for quantitative trait loci affecting growth-related traits in an F1 family of Asian seabass (Lates calcarifer). BMC Genomics, 2006, 7: 274

22 Wang CM, Lo LC, Feng F, Zhu ZY, Yue GH. Identification and verification of QTL associated with growth traits in two genetic backgrounds of Barramundi (Lates calcarifer). Anim Genet, 2008, 39: 34-39

23 O'malley KG, Sakamoto T, Danzmann RG, Ferguson MM. Quantitative trait loci for spawning date and body weight in rainbow trout: testing for conserved effects across ancestrally duplicated chromosomes. J Hered, 2003, 94: 273-284

24 Wringe BF, Devlin RH, Ferguson MM, Moghadam HK, Sakhrani D, Danzmann RG. Growth-related quantitative trait loci in domestic and wild rainbow trout (Oncorhynchus mykiss). BMC Genet, 2010, 11: 63

25 Reid DP, Szanto A, Glebe B, Danzmann RG, Ferguson MM. QTL for body weight and condition factor in Atlantic salmon (Salmo salar): comparative analysis with rainbow trout (Oncorhynchus mykiss) and Arctic charr (Salvelinus alpinus). Heredity, 2004, 94: 166-172

26 Houston RD, Bishop SC, Hamilton A, Guy DR, Tinch AE, Taggart JB, Derayat A, McAndrew BJ, Haley CS. Detection of QTL affecting harvest traits in a commercial Atlantic salmon population. Anim
Genet, 2009, 40: 753-755

27 Gutierrez AP, Lubieniecki KP, Davidson EA, Lien S, Kent MP, Fukui S, Withler RE, Swift B, Davidson WS. (2012) Genetic mapping of quantitative trait loci (QTL) for body-weight in Atlantic salmon (Salmo salar) using a $6.5 \mathrm{~K}$ SNP array. Aquaculture, 2012, 358: 61-70

28 Cnaani A, Hallerman EM, Ron M, Weller JI, Indelman M, Kashi Y, Gall GAE, Hulata G. Detection of a chromosomal region with two quantitative trait loci, affecting cold tolerance and fish size, in an F2 tilapia hybrid. Aquaculture, 2003, 223: 117-128

29 Cnaani A, Zilberman N, Tinman S, Hulata G, Ron M. Genome-scan analysis for quantitative trait loci in an F2 tilapia hybrid. Mol Genet Genomics, 2004, 272: 162-172

30 Tao WJ, Boulding EG. Associations between single nucleotide polymorphisms in candidate genes and growth rate in Arctic charr (Salvelinus alpinus L.). Heredity, 2003, 91:60-69

31 Li XH, Bai JJ, Ye X, Hu YC, Li SJ, Yu LY. Polymorphisms in the 5' flanking region of the insulin-like growth factor I gene are associated with growth traits in largemouth bass Micropterus salmoides. Fish Sci, 2009, 75: 351-358

32 Sun YH, Yu X, Tong J. Polymorphisms in myostatin gene and associations with growth traits in common carp. Int J Mol Sci, 2012, 13: 14956-14961

33 Liu L, Yu X, Tong J. Molecular characterization of myostatin (MSTN) gene and association analysis with growth traits in the bighead carp (Aristichthys nobilis). Mol Biol Rep, 2012, 39: 9211-9221

34 Rodriguez MF, LaPatra S, Williams S, Famula T, May B. Genetic markers associated with resistance to infectious hematopoietic necrosis in rainbow and steelhead trout (Oncorhynchus mykiss) backcrosses. Aquaculture, 2004, 241:93-115

35 Ozaki A, Sakamoto T, Khoo S, Nakamura K, Coimbra MR, Akutsu T, Okamoto N. Quantitative trait loci (QTLs) associated with resistance/susceptibility to infectious pancreatic necrosis virus (IPNV) in rainbow trout (Oncorhynchus mykiss). Mol Genet Genomics, 2001, 265: 23-31

36 Baerwald MR, Petersen JL, Hedrick RP, Schisler GJ, May B. A major effect quantitative trait locus for whirling disease resistance identified in rainbow trout (Oncorhynchus mykiss). Heredity, 2011, 106: 920-926

37 Moen T, Baranski M, Sonesson AK, Kjøglum S. Confirmation and fine-mapping of a major QTL for resistance to infectious pancreatic necrosis in Atlantic salmon (Salmo salar): population-level associations between markers and trait. BMC Genomics, 2009, 10: 368

38 Houston RD, Guy DR, Hamilton A, Ralph J, Spreckley N, Taggart JB, McAndrew BJ, Haley CS, Bishop SC. Mapping QTL affecting resistance to infectious pancreatic necrosis (IPN) in Atlantic salmon (Salmo salar). Aquaculture, 2007, 272: S269

39 Houston RD, Haley CS, Hamilton A, Guy DR, Tinch AE , Taggart JB, McAndrew BJ, Bishop SC. Major quantitative trait loci affect resistance to infectious pancreatic necrosis in Atlantic salmon (Salmo salar). Genetics, 2008, 178, 1109-1115

40 Houston RD, Haley CS, Hamilton A, Guy DR, Mota-Velasco JC, Gheyas AA, Tinch AE, Taggart JB, Bron JE, Starkey WG, McAndrew BJ, Verner-Jeffreys DW, Paley RK, Rimmer GSE, Tew IJ, Bishop SC. The susceptibility of Atlantic salmon fry to freshwater infectious pancreatic necrosis is largely explained by a major QTL. Heredity, 2009, 105: 318-327

41 Gheyas AA, Haley CS, Guy DR, Hamilton A, Tinch AE, Mota-Velasco JC, Woolliams JA. Effect of a major QTL affecting IPN resistance on production traits in Atlantic salmon. Anim Genet, 2010, 41: 666-668

42 Fuji K, Kobayashi K, Hasegawa O, Coimbra MRM, Sakamoto T, Okamoto N. Identification of a single major genetic locus controlling the resistance to lymphocystis disease in Japanese flounder (Paralichthys olivaceus). Aquaculture, 2006, 254: 203-210

43 Fuji K, Hasegawa O, Honda K, Kumasaka K, Sakamoto T, Okamoto N. Marker-assisted breeding of a lymphocystis disease-resistant Japanese flounder (Paralichthys olivaceus). Aquaculture, 2007, 272: 
291-295

44 Palti Y, Nichols KM, Waller KI, Parsons JE, Thorgaard GH. Association between DNA polymorphisms tightly linked to MHC class II genes and IHN virus resistance in backcrosses of rainbow and cutthroat trout. Aquaculture, 2001, 194: 283-389

45 Zhang YX, Chen SL, Liu YG, Sha ZX, Liu ZJ. Major histocompatibility complex class IIB allele polymorphism and its association with resistance/susceptibility to Vibrio anguillarum in Japanese flounder (Paralichthys olivaceus). Mar Biotechnol, 2006, 8: 600-610

$46 \mathrm{Xu}$ TJ, Chen SL, Zhang YX. MHC class II $\alpha$ gene polymorphism and its association with resistance/susceptibility to Vibrio anguillarum in Japanese flounder (Paralichthys olivaceus). Dev Comp Immunol, 2010, 34: 1042-1050

47 Nkrumah JD, Sherman EL, Li C, Marques E, Crews Jr DH, Bartusiak R, Murdoch B, Wang Z, Basarab JA, Moore SS. Primary genome scan to identify putative quantitative trait loci for feedlot growth rate, feed intake, and feed efficiency of beef cattle. J Anim Sci, 2007, 85: 3170-3181

48 Houston RD, Haley CS, Archibald AL, Rance KA. A QTL affecting daily feed intake maps to Chromosome 2 in pigs. Mamm Genome, 2005, 16: 464-470

49 Van Kaam JB, Groenen MA, Bovenhuis H, Veenendaal A, Vereijken AL, Van Arendonk JA. Whole genome scan in chickens for quantitative trait loci affecting growth and feed efficiency. Poultry Sci, 1999, 78: $15-23$

50 Sherman EL, Nkrumah JD, Murdoch BM, Li C, Wang Z, Fu A, Moore SS. Polymorphisms and haplotypes in the bovine neuropeptide Y, growth hormone receptor, ghrelin, insulin-like growth factor 2, and uncoupling proteins 2 and 3 genes and their associations with measures of growth, performance, feed efficiency, and carcass merit in beef cattle. J Anim Sci, 2008, 86: 1-16

51 Liu ZJ. Gene mapping, marker-assisted selection, gene cloning, genetic engineering and integrated genetic improvement programs at Auburn University. In: Gupta MV, Acosta BO, eds. Fish Genetics Research in Member Countries and Institutions of the International Network on Genetics in Aquaculture, ICLARM Conf Proc, 2001, 64: 179

52 Zimmerman AM, Wheeler PA, Ristow SS, Thorgaard GH. Composite interval mapping reveals three QTL associated with pyloric caeca number in rainbow trout, Oncorhynchus mykiss. Aquaculture, 2005, 247: 85-95

53 Wang XP, Zhang XF, Li WS, Zhang TQ, Li C, Sun XW. Mapping and genetic effect analysis on quantitative trait loci related to feed conversion ratio of common carp (Cyprinus Carpio L.) (in Chinese). Acta Hydrobiol Sin, 2012, 36: 177-196

54 Lee BY, Hulata G, Kocher TD. Two unlinked loci controlling the sex of blue tilapia (Oreochromis aureus). Heredity, 2004, 92: 543-549

55 Alfaqih MA, Brunelli JP, Drew RE, Thorgaard GH. Mapping of five candidate sex-determining loci in rainbow trout (Oncorhynchus mykiss). BMC Genet, 2009, 10: 2

56 Davidson WS, Huang TK, Fujiki K, von Schalburg KR, Koop BF. The sex determining loci and sex chromosomes in the family Salmonidae. Sex Dev, 2009, 3: 78-87

57 Cnaani A, Lee BY, Zilberman N, Ozouf-Costaz C, Hulata G, Ron M, D'Hont A, Baroiller JF, D'Cotta H, Penman DJ, Tomasino E, Coutanceau JP, Pepey E, Shirak A, Kocher TD. Genetics of sex determination in tilapiine species. Sex Dev, 2008, 2: 43-54

58 Eshel O, Shirak A, Weller JI, Slossman T, Hulata G, Cnaani A, Ron M. Fine-mapping of a locus on linkage group 23 for sex determination in Nile tilapia (Oreochromis niloticus). Anim Genet, 2011, 42: 222-224

59 Eshel O, Shirak A, Weller JI, Hulata G, Ron M. Linkage and physical mapping of sex region on LG23 of Nile tilapia (Oreochromis niloticus). G3: Genes-Genom-Genet, 2012, 2: 35-42

60 Sun YL, Jiang DN, Zeng S, Hu CJ, Ye K, Yang C, Yang SJ, Li MH, Wang DS. Screening and characterization of sex-linked DNA markers and marker-assisted selection in the Nile tilapia (Oreochromis niloticus). Aquaculture, 2014, 433: 19-27

61 Sakamoto T, Danzmann RG, Gharbi K, Howard P, Ozaki A, Khoo
SK, Woram RA, Okamoto N, Ferguson MM, Holm L, Guyomard R, Hoyheim B. A microsatellite linkage map of rainbow trout $(\mathrm{On}$ corhynchus mykiss) characterized by large sex-specific differences in recombination rates. Genetics, 2000, 155: 1331-1345

62 Perry GML, Ferguson MM, Sakamoto T, Danzmann RG. Sex-linked quantitative trait loci for thermotolerance and length in the rainbow trout. J Hered, 2005, 96: 97-107

63 Moghadam HK, Poissant J, Fotherby H, Haidle L, Ferguson MM, Danzmann RG. Quantitative trait loci for body weight, condition factor and age at sexual maturation in Arctic charr (Salvelinus alpinus): comparative analysis with rainbow trout (Oncorhynchus mykiss) and Atlantic salmon (Salmo salar). Mol Genet Genomics, 2007, 277: 647-661

64 Gharbi K, Gautier A, Danzmann RG, Gharbi S, Sakamoto T, Høyheim B, Taggart JB, Cairney M, Powell R, Krieg F, Okamoto N, Ferguson MM, Holm L, Guyomard R. A linkage map for brown trout (Salmo trutta): chromosome homeologies and comparative genome organization with other salmonid fish. Genetics, 2006, 172: 2405-2419

65 Gilbey J, Verspoor E, McLay A, Houlihan D. A microsatellite linkage map for Atlantic salmon (Salmo salar). Anim Genet, 2004, 35: 98-105

66 Woram RA, Gharbi K, Sakamoto T, Hoyheim B, Holm L, Naish K, McGowan C, Ferguson MM, Phillips RB, Stein J, Guyomard R, Cairney M, Taggart JB, Powell R, Davidson W, Danzmann RG. Comparative genome analysis of the primary sex-determining locus in salmonid fishes. Genome Res, 2003, 13: 272-280

67 Loukovitis D, Sarropoulou E, Tsigenopoulos CS, Batargias C, Magoulas A, Apostolidis AP, Chatziplis D, Kotoulas G. Quantitative trait loci involved in sex determination and body growth in the gilthead sea bream (Sparus aurata L.) through targeted genome scan. PLoS One, 2011, 6: e16599

68 Martínez P, Bouza C, Hermida M, Fernández J, Toro MA, Vera M, Pardo B, Millán A, Fernández C, Vilas R, Viñas A, Sánchez L, Felip A, Piferrer F, Ferreiro I, Cabaleiro S. Identification of the major sex-determining region of turbot (Scophthalmus maximus). Genetics, 2009, 183: 1443-1452

69 Viñas A, Taboada X, Vale L, Robledo D, Hermida M, Vera M, Martínez P. Mapping of DNA sex-specific markers and genes related to sex differentiation in turbot (Scophthalmus maximus). Mar Biotechnol, 2012, 14: 655-663

70 Chen S, Zhang G, Shao C, Huang Q, Liu G, Zhang P, Song W, An N, Chalopin D, Volff J, Hong Y, Li Q, Sha Z, Zhou H, Xie M, Yu Q, Liu Y, Xiang H, Wang N, Wu K, Yang C, Zhou Q, Liao X, Yang L, Hu Q, Zhang J, Meng L, Jin L, Tian Y, Lian J, Yang J, Miao G, Liu S, Liang Z, Yan F, Li Y, Sun B, Zhang H, Zhang J, Zhu Y, Du M, Zhao Y, Schartl M, Tang Q, Wang J. Whole-genome sequence of a flatfish provides insights into $\mathrm{ZW}$ sex chromosome evolution and adaptation to a benthic lifestyle. Nat Genet, 2014, 46: 253-260

71 Barrett RD, Paccard A, Healy TM, Bergek S, Schulte PM, Schluter D, Rogers SM. Rapid evolution of cold tolerance in stickleback. Proc Biol Sci, 2011, 278: 233-238

72 Moen T, Agresti JJ, Cnaani A, Moses H, Famula TR, Hulata G, Gall GAE, May B. A genome scan of a four-way tilapia cross supports the existence of a quantitative trait locus for cold tolerance on linkage group 23. Aquac Res, 2004, 35: 893-904

73 Jackson TR, Ferguson MM, Danzmann RG, Fishback AG, Ihssen PE, O'Connell M, Crease TJ. Identification of two QTL influencing upper temperature tolerance in three rainbow trout (Oncorhynchus mykiss) half-sib families. Heredity, 1998, 80: 143-151

74 Danzmann RG, Jackson TR, Ferguson MM. Epistasis in allelic expression at upper temperature tolerance QTL in rainbow trout. Aquaculture, 1999, 173: 45-58

75 Perry GML, Danzmann RG, Ferguson MM, Gibson JP. Quantitative trait loci for upper thermal tolerance in outbred strains of rainbow trout (Oncorhynchus mykiss). Heredity, 2001, 86: 333-341

76 Sun XW, Liang LQ. A genetic linkage map of common carp (Cyprinus carpio L.) and mapping of a locus associated with cold tolerance. 
Aquaculture, 2004, 238: 165-172

77 Rengmark AH, Slettan A, Lee WJ, Lie $\varnothing$, Lingaas F. Identification and mapping of genes associated with salt tolerance in tilapia. J Fish Biol, 2007, 71(sc): 409-422

78 Norman JD, Robinson M, Glebe B, Ferguson MM, Danzmann RG. Genomic arrangement of salinity tolerance QTLs in salmonids: a comparative analysis of Atlantic salmon (Salmo salar) with Arctic charr (Salvelinus alpinus) and rainbow trout (Oncorhynchus mykiss). BMC Genomics, 2012, 13: 420

79 Zhai YH, Zhou L, Wang Y, Wang ZW, Li Z, Zhang XJ, Gui JF. Proliferation and resistance difference of a liver-parasitized myxosporean in two different gynogenetic clones of gibel carp. Parasitol Res, 2014, 113: $1331-1341$

$80 \mathrm{Xu}$ TJ, Chen SL, Ji XS, Tian YS. MHC polymorphism and disease resistance to Vibrio anguillarum in 12 selective Japanese flounder (Paralichthys olivaceus) families. Fish Shellfish Immun, 2008, 25: 213-221

81 Wang L, Fan C, Liu Y, Zhang Y, Liu S, Sun D, Deng H, Xu Y, Tian Y, Liao X, Xie M, Li W, Chen S. A genome scan for quantitative trait loci associated with Vibrio anguillarum infection resistance in Japanese flounder (Paralichthys olivaceus) by bulked segregant analysis. Mar Biotechnol, 2014, 16: 513-521

82 Wang D, Mao HL, Chen HX, Liu HQ, Gui JF. Isolation of Y- and $\mathrm{X}$-linked SCAR markers in yellow catfish and application in the production of all-male populations. Anim Genet, 2009, 40: 978-981

83 Liu HQ, Guan B, Xu J, Hou C, Tian H, Chen H. Genetic manipulation of sex ratio for the large-scale breeding of YY super-male and $\mathrm{XY}$ all-male yellow catfish (Pelteobagrus fulvidraco (Richardson)). Mar Biotechnol, 2013, 15: 321-328

84 Dan C, Mei J, Wang D, Gui JF. Genetic differentiation and efficient sex-specific marker development of a pair of Y-and X-linked markers in yellow catfish. Int J Biol Sci, 2013, 9:1043-1049
85 Che SL, Li J, Deng SP, Tian YS, Wang QY, Zhuang ZM, Sha ZX, $\mathrm{Xu}$ JY. Isolation of female-specific AFLP markers and molecular identification of genetic sex in half-smooth tongue sole (Cynoglossus semilaevis). Mar Biotechnol, 2007, 9: 273-280

86 Chen SL, Ji XS, Shao CW, Li WL, Yang JF, Liang Z, Liao XL, Xu $\mathrm{GB}, \mathrm{Xu} \mathrm{Y}$, Song WT. Induction of mitogynogenetic diploids and identification of WW super-female using sex-specific SSR markers in half-smooth tongue sole (Cynoglossus semilaevis). Mar Biotechnol, 2012, 14: 120-128

87 Xu P, Zhang X, Wang X, Li J, Liu G, Kuang Y, Xu J, Zheng X, Ren L, Wang G, Zhang Y, Huo L, Zhao Z, Cao D, Lu C, Li C, Zhou Y, Liu Z, Fan Z, Shan G, Li X, Wu S, Song L, Hou G, Jiang Y, Jeney Z, Yu D, Wang L, Shao C, Song L, Sun J, Ji P, Wang J, Li Q, Xu L, Sun F, Feng J, Wang C, Wang S, Wang B, Li Y, Zhu Y, Xue W, Zhao L, Wang J, Gu Y, Lv W, Wu K, Xiao J, Wu J, Zhang Z, Yu J, Sun X. Genome sequence and genetic diversity of the common carp, Cyprinus carpio. Nat Genet, 2014, 46: 1212-1219

88 Ron M, Weller JI. From QTL to QTN identification in livestockwinning by points rather than knock-out: a review. Anim Genet, 2007, 38: 429-439

89 Remington DL, Thornsberry JM, Matsuoka Y, Wilson LM, Whitt SR, Doebley J, Kresovich S, Goodman MM, Buckler ES. Structure of linkage disequilibrium and phenotypic associations in the maize genome. Proc Natl Acad Sci USA, 2001, 98: 11479-11484

90 De-Santis C, Jerry DR. Candidate growth genes in finfish-Where should we be looking? Aquaculture, 2007, 272: 22-38

91 Lee BY, Penman DJ, Kocher TD. Identification of a sex determining region in Nile tilapia (Oreochromis niloticus) using bulked segregant analysis. Anim Genet, 2003, 34: 379-383

92 Moose SP, Mumm RH. Molecular plant breeding as the foundation for 21st century crop improvement. Plant Physiol, 2008, 147: 969-977

Open Access This article is distributed under the terms of the Creative Commons Attribution License which permits any use, distribution, and reproduction in any medium, provided the original author(s) and source are credited. 